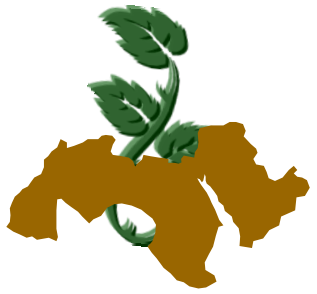

Arab Univ.

J. Agric. Sci.,

Ain Shams Univ.,

Cairo, 16(1), 97-114, 2008

\title{
EVALUATION OF ANTIOXIDANT ACTIVITY OF SOME SPICES AND THEIR APPLICATION IN CROISSANT AND FILLING CREAM
}

\author{
Hanan, M.A. Al-Sayed 1 \\ 1- Food Sci. Dept., Fac. of Agric., Ain Shams University, Shoubra El-Kheima, Cairo, Egypt
}

Keywords: Anise, Antioxidant Activity, Caraway, Carob, Cinnamon, Fennel, Ginger

\begin{abstract}
Natural antioxidants have gained considerable interest in recent years for their role in preventing the auto oxidation of fats, oils and fat containing food products. In this study, six spices containing natural antioxidants were evaluated for their retarding fat oxidation compared to butylated hydroxyl toluene (BHT). The yield obtained from water extract of the tested spices ranged between $20 \%$ and $50 \%$. Carob gave the highest yield followed by anise and cinnamon, then caraway and fennel, while ginger gave the lowest yield .The free radical scavenging activities measured by 2diphenyl-1-picryl-hydrazyl (DPPH) were $88.08 \%$, $81.69 \%, 79.62 \%, 78.93 \%, 73.06 \%$, and $71.50 \%$ for cinnamon, anise, carob, caraway ginger, and fennel, respectively at concentration of 2250 $\mu \mathrm{g} / \mathrm{ml}$. Cinnamon showed higher antioxidant activity on linoleic acid oxidation than BHT followed by anise, carob and ginger. While, fennel and caraway recorded closely antioxidant activity to that of BHT at low concentration of $100 \mu \mathrm{g} / \mathrm{ml}$. Total phenolic content of the tested spices varied ranging from 11.19 to $22.95 \mathrm{mg}$ as gallic acid / gm dry extract in carob and caraway, respectively. Depending upon the sensory evaluation of croissant containing different levels of tested spices, a concentration of $1.5 \%$ of anise, caraway fennel and cinnamon was chosen, while the chosen concentration of ginger was $2.5 \%$ and carob was $1 \%$ for testing their effectiveness against oxidation of lipid in croissant. However, a concentration of $2 \%$ of anise, fennel, ginger and carob was chosen while, the chosen concentration of caraway and cinnamon was $1 \%$ for testing their effectiveness against oxidation of lipid in filling cream. Addi-
\end{abstract}

tion of tested spices gave an excellent antioxidant effect on croissant and filling cream compared with the effect of BHT. The increase in both peroxide and acid values after 14 and 28 days respectively were lower than of control and BHT. Carob, ginger, caraway and cinnamon were more effective in controlling lipid oxidation during storage. In conclusion addition of tested spices as sources of effective natural antioxidants retarded lipid oxidation and maintain the quality of croissant and filling cream during storage.

\section{INTRODUCTION}

Antioxidant compounds in food play important roles as health-protecting factor. Antioxidants are also widely used as additives in fats and oils and in food processing to prevent or delay spoilage of foods. Spices and some herbs have received increased attention as sources of many effective antioxidants, (Suhaj, 2006).

Lipid oxidation and bacterial contamination are the main factor that determine food quality loss and shelf-life reduction. Therefore, delaying lipid oxidation and preventing bacterial crosscontamination are highly relevant to food processors, (Decker, et al 1995).

The use of synthetic antioxidants in food products is being questioned, consumers have also become more cautious about the nutritional quality and safety of food additives. In food industry, antioxidants are used to retard the oxidative degradation of fats by inhibiting the formation of free radicals. Synthetic antioxidants, such as butylated hydroxyl toluene (BHT), butylated hydroxyl anisol (BHA) and propylgallate (PG) are widely used. (Shahidi, 2000 and Kosar, et al 2007).

There are some serious problems concerning the safety and toxicity of such synthetic antioxidants related to their metabolism and possible ab- 
sorption and accumulation in body organ and tissues. (Linderschmidt, et al 1986).

Many antioxidant compounds, naturally occurring in plant sources have been identified as free radicals or active oxygen scavengers. Recently, interest has considerably increased in finding naturally occurring antioxidant for use in foods or medicinal materials to replace synthetic antioxidants, which are being restricted due to their side effects such as carcinogenicity (Zheng and Wang, 2001). There is a growing interest in the use of natural antioxidants for increasing the shelf life of foods. This is mainly due to an obvious consumer preference for natural ingredients combined with concerns about toxic effects of synthetic antioxidant activities. (Puertas-Meji et al 2002).

A great number of spices and aromatic herbs contain chemical compounds exhibiting antioxidant properties. These properties are attributed to a variety of active phytochemicals including vitamins, carotenoids, terpenoids, alkaloids, flavonoids, lignin, simple phenols and phenolic acids, etc. (Liu and Ng, 2000). Spices can be add to foods in several forms as whole spices, as ground spices, or as isolates from their extracts. spices are aromatic and pungent food ingredient (Suhaj, 2006).

Anise (Pimpinella anisum L.) is an annual herb and a grassy plant with white flowers and small green to yellow seeds. Anise seed, one of its various extracts, or the soluble from of spice is used in seasoning for dry sausage (Farrell, 1985 and Gulcin, et al 2003).

Carob has long been eaten as food. A part from being chewed as a sweetmeat, carob pods are processed to a cocoa -like flour which is added to cold or heated milk for drinking. It has been combined with wheat flour in making bread or pancakes and used in ice cream, salad dressings, sauces, canned meats and fish, jelly, mustard, and other food products. (Morton, 1987 and Greally $\boldsymbol{e t}$ al 1992).

Ginger is the common name for the monocotyledonous perennial plant Zingiber officinale, the edible part of the plant is commonly used as aspic in some parts of the Middle East its powder is used as a spice for coffee, (Taghizadeh, 2007).

Cinnamon (Cinnamonum zeylanicum) is reddishbrown and has a warm, spicy, woody aromatic and used commercially in confections, ice cream, chewing gums and sauces. Cinnamon are often used as flavoring cereals (Farrell, 1985 and Archer, 1988).
Fennel (Foeniculum vulgare) flavor has been described as being warm, spicy, anise like, green herbaceous. Fennl seed is used in soups, sausage, tomato dishes and meat. Caraway seed (carum carvi L.) have a characteristic agreeable odor, and aromatic, pleasant, warm, sharp test. Caraway seed is used in many of baked goods-breads, roast goose, seafoods and cabbage, potato soups (Farrell, 1985).

Reddy, et al (2005) evaluated the antioxidant activity of some plant extracts and their application in biscuits and found that the addition of extracts of amla (Emblica officianalis), drumstick leves (Moringa oleifera) and raisins (Vitis vinifera) gave an excellent antioxidant effect on the biscuits compared with the effect of BHA.

Cake manufactures face a major problem of lipid oxidation and mould growth which limits the shelf-life of their products. The use of antioxidants and preservatives can reduce this problem (Lean and Mohamed, 1999).

The objective of this work was to evaluate the effect of six spices ( anise ,caraway ,fennel, cinnamon, ginger and carob ) as antioxidant compared with (BHT) and to investigate the possibility of their application at the best selected concentration as natural antioxidant in croissant and filling cream.

\section{MATERIALS AND METHODS}

\section{Materials}

\subsection{Spices}

Anise, caraway, fennel, cinnamon, ginger and carob were purchased from local market at Cairo.

\subsection{Croissant and filling cream ingredients}

Wheat flour was obtained from Cairo South Company of Milling (EL-Haram Milling). Corn oil, fine sucrose (commercial grade), fresh yeast, salt, shortening and margarine were purchased from local market, Cairo. Egypt. Non fat milk was obtained from Dena farm.

\subsection{Chemicals}

Potassium sorbet was obtained from Gomhoria, Company, Egypt. Folin-Cioccalte Reagent, butylated hydroxyl toluene (BHT), 2, 2-diphenyl1-picryl-hydrazyl (DPPH), gallic acid, linoliec fatty acid were obtained from Sigma-Aldrich Chime, Germany. 


\section{Methods}

\subsection{Preparation of water extracts and its yield of tested spices}

For water extraction, $1 \mathrm{~g}$ sample of spice in a fine powder form was extracted with $20 \mathrm{ml}$ boiling water using magnetic stirrer for $15 \mathrm{~min}$ then, the extract was filtered over whatman No. 1 paper (Gulcin, et al 2003). The filterate was then dried at $70^{\circ} \mathrm{C}$ in air oven and the yield was calculated in percent of spice.

\subsection{Evaluation of antioxidant activity of tested spices}

Antioxidant activity of tested spices were tested individually in comparison with a synthetic antioxidant (BHT) as follows:-

\subsubsection{Free radical scavenging activity (DPPH test)}

The free radical scavenging activity of tested spices was measured by 2,2 diphenyl-1-picrylhydrazil (DPPH) method according to Tepe et al (2005) One $\mathrm{ml}$ of $0.1 \mathrm{mM}$ methanolic solution of DPPH was added to $3 \mathrm{ml}$ of various concentrations of each spices $(250-2250 \mu \mathrm{g}$ spice/ml). After 30 min incubation period at ambient temperature, the absorbance of the reaction was measured against a blank at $517 \mathrm{~nm}$ using spectrophotometer Shimadzu UIV-1201 (Shimadzu Co., Ltd., Kyoto, Japan). Lower absorbance of the reaction mixture indicates higher free radical scavenging activity. Inhibition of free radical scavenging in percent was calculated using the following equation:-

$$
\text { Inhibition \% = (A0 - As / A0) } \times 100
$$

Where:

A0 : the absorbance of control

As : the absorbance of the test sample

\subsubsection{Linoleic acid emulsion test}

Antioxidant activity of tested spices was determined using a diene conjugated formation (linoleic acid emulsion) method according to Lingnert, et al (1979). A substrate consisted of $2.86 \mathrm{~g}$ of linoleic acid emulsified with an equal amount of Tween 20 in phosphate buffer, pH $7.0(0.1 \mathrm{~mol} / 1)$. at high speed for $1 \mathrm{~min}$. Different concentrations of each spice (100, 200, 400 and $600 \mu \mathrm{g}$ spice/ml) were mixed with $5 \mathrm{ml}$ emulsions and incubated at $50^{\circ} \mathrm{C}$ for $20 \mathrm{~h}$. Absorbance was then measured at
$234 \mathrm{~nm}$ using spectrophotometer Shimadzu UIV1201 (Shimadzu Co., Ltd., Kyoto, Japan).

\subsubsection{Determination of total phenolic com- pounds}

Total phenolic compounds in water extracts of tested spices were determined with Folin- Cioclteu reagent according to the method of Slinkard and Singleton (1977). One $\mathrm{ml}$ of water extract of each spice was mixed thoroughly in test tube with $1 \mathrm{ml}$ of Folin-Cioclteu reagent. Three minutes later, $3 \mathrm{ml}$ of $\mathrm{Na} 2 \mathrm{CO} 3$ was added and the mixture was allowed to stand for $2 \mathrm{~h}$ with intermittent shaking. The absorbance was measured at $760 \mathrm{~nm}$ using spectrophotometer Shimadzu UIV-1201 (Shimadzu Co., Ltd., Kyoto, Japan). The concentration of total phenolic compounds in water extract of spice was determined as milligrams of gallic acid equivalent per gram of dry extract weigh according to Gulcin, et al (2003).

\section{Technological methods}

\subsection{Croissant manufacture}

Croissant was prepared using the suggested formula according to Sternbagen and Hoseney (1994).

Wheat flour, corn oil, salt, non fat milk, fine sucrose, fresh yeast and different concentrations of tested spices were mixed with a sufficient amount of water to form dough with constant consistency. The dough was then rested for $15 \mathrm{~min}$, before incorporating $0.4 \mathrm{~kg}$ of layering fat (margarine) by envelope method. The paste was rested for another $15 \mathrm{~min}$ more and gauged to $10 \mathrm{~mm}$ thickness by using sheeter, the sheet was gauged to $8 \mathrm{~min}$, and then the ends were folded first and then folded again like book. After anther $15 \mathrm{~min}$ of rest period, the paste was gauged to $7 \mathrm{~min}$ thickness and given two fourfold turns before final gauging to $3.0 \mathrm{~mm}$. The paste was cut into triangular pieces. The pastries were placed into a proofing cabinet and proofed at $85 \%$ humidity and $38^{\circ} \mathrm{C}$ to $60 \mathrm{~min}$, then the pastries were baked at $85 \%$ humidity and $38^{\circ} \mathrm{C}$ for $60 \mathrm{~min}$, then the pastries were baked at $225^{\circ} \mathrm{C}$ for $25 \mathrm{~min}$. Thereafter pastries were allowed to cool at room temperature before organoleptic evaluation.

\subsection{Filling cream manufacture}

Filling cream was prepared using the modified formula according to Jeffery, (1993). 


\section{Croissant}

\begin{tabular}{|c|c|c|c|c|c|c|c|}
\hline Flour & Corn oil & Salt & Fresh yeast & Fine sucrose & Non fat milk & Potassium sorbet & Margarine \\
\hline $1.0 \mathrm{~kg}$ & $100 \mathrm{~g}$ & $15 \mathrm{~g}$ & $15 \mathrm{~g}$ & $100 \mathrm{~g}$ & $40 \mathrm{~g}$ & $1.0 \mathrm{~g}$ & $400 \mathrm{~g}$ \\
\hline
\end{tabular}

Filling cream

\begin{tabular}{|c|c|c|c|c|c|}
\hline Fine sucrose & Shortening & Lecithin & Salt & Non fat milk & Potassium sorbet \\
\hline $62.55 \mathrm{~g}$ & $34.78 \mathrm{~g}$ & $0.05 \mathrm{~g}$ & $0.04 \mathrm{~g}$ & $2.48 \mathrm{~g}$ & 0.10 \\
\hline
\end{tabular}

The shortening was creamed for 3 min then fin sucrose was added to the creamed shortening and beaten for $5 \mathrm{~min}$. The other ingredient and different concentrations of tested spices were added gradually on the (sugar-fat mixture) and beaten for $3 \mathrm{~min}$. Thereafter, evaluate the sensory properties of filling cream.

\section{Chemical analysis}

Moisture content, Peroxide and acid values of extracted lipids from croissant and filling cream containing tested spices were determined according to A.O.A.C., (2000).

\section{Sensory evaluation}

A10 panelists from the staff members of the Food Science Department. Faculty of Agriculture, Ain Shams. University were asked to evaluate appearance, color, odor, taste and overall acceptability of the processed filling cream. They were also asked to evaluate texture, crust color, crumb color, taste and overall acceptability of the processed croissant according to Bennion and Bamford, (1983).

\section{Statistical analysis}

The experimental data were analyzed using analysis of variance and Duncan's multplie range test at $(\mathrm{P}<0.05)$. The data were analyzed according to User's Guide of Statistical Analysis System at computing center of Faculty of Agriculture, Ain Shams University (SAS, 1996).

\section{RESULTS AND DISCUSSION}

\section{Water extraction Yield of tested spices}

The percentage yield obtained from water extract of tested spices is represented in Fig. (1). It was clear that carob gave the highest yield, followed by anise and cinnamon then caraway and fennel. being 50, 40, 40, 30, 30 and gm / 100gm dry spices respectively while ginger gave the lowest yield, it was 20\%. Different finding were reported by Yen and Chuang, (2002), they found the yield obtained from water extract of (Cassia tora L.) was $2.58 \%$. Kosar, et al (2007) found that the yield obtained with methanolic extract of sumac was $29.77 \%$.

\section{Antioxidant activity of tested spices}

Antioxidant activity of tested spices was carried out by two tests, namely DPPH test and linoleic acid emulsion test :-

\subsection{DPPH radical scavenging activity}

Relatively stable organic radical DPPH has been widely used in determining of antioxidant activity of single compounds as well as different plant extracts. The method is based on the reduction of alcoholic DPPH solution in the presence of a hydrogen donating antioxidant. The reduction capability of DPPH radicals was determined by the decrease in its absorbance at $517 \mathrm{~nm}$, which is induced by antioxidants. (Yamaguchi et al 1998).

Free radical- scavenging capacity of different concentrations of some spices measured by DPPH are given in Fig. (2). DPPH radical scavenging activities (\%) were increased with increasing concentration of tested spices from (250 to 2250 $\mu \mathrm{g} / \mathrm{gm})$. The water extract of anise at high concentration $(2250 \mu \mathrm{g} / \mathrm{gm})$ showed similar antioxidant activity to that of BHT. Cinnamon at concentrations of 750 and $2250 \mu \mathrm{g} / \mathrm{gm}$ notably reduced significantly DPPH free radical, with an efficacy much greater than the reference BHT being $83.07 \%, 88.08 \%$ and $81.35 \%$ respectively. On the other hand, the least DPPH inhibition was recorded by carob $20.50 \%$ at concentration of 


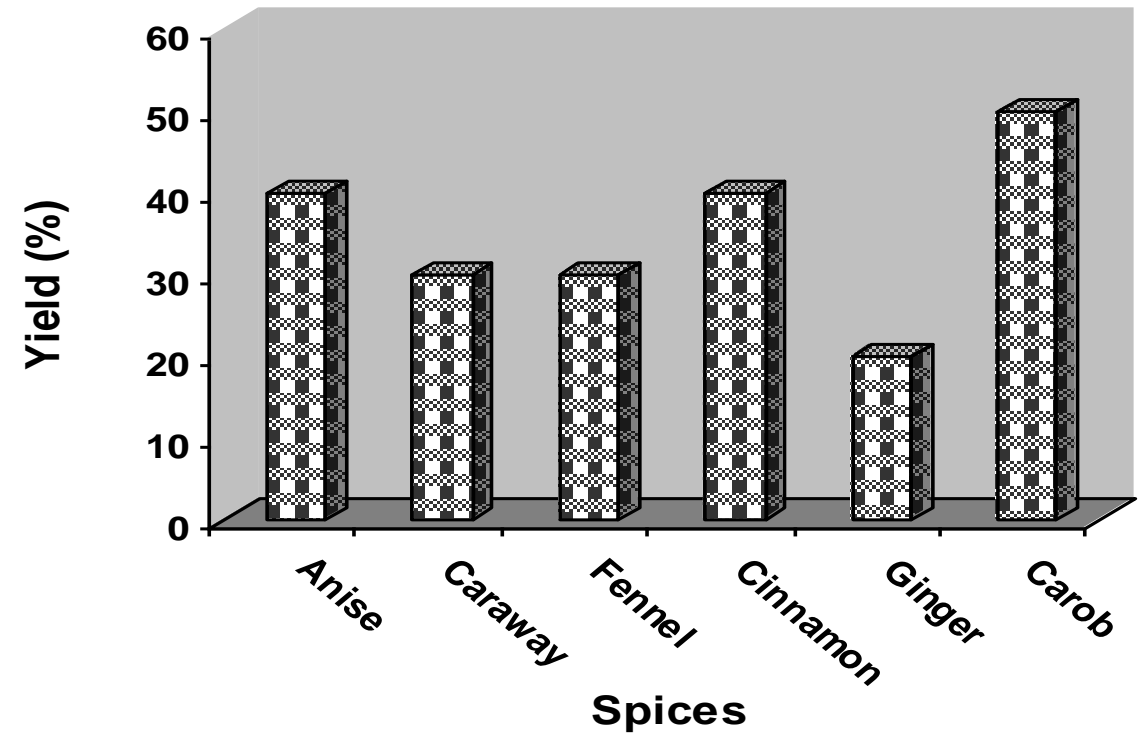

Figure 1. Yield (\%) of the tested spices

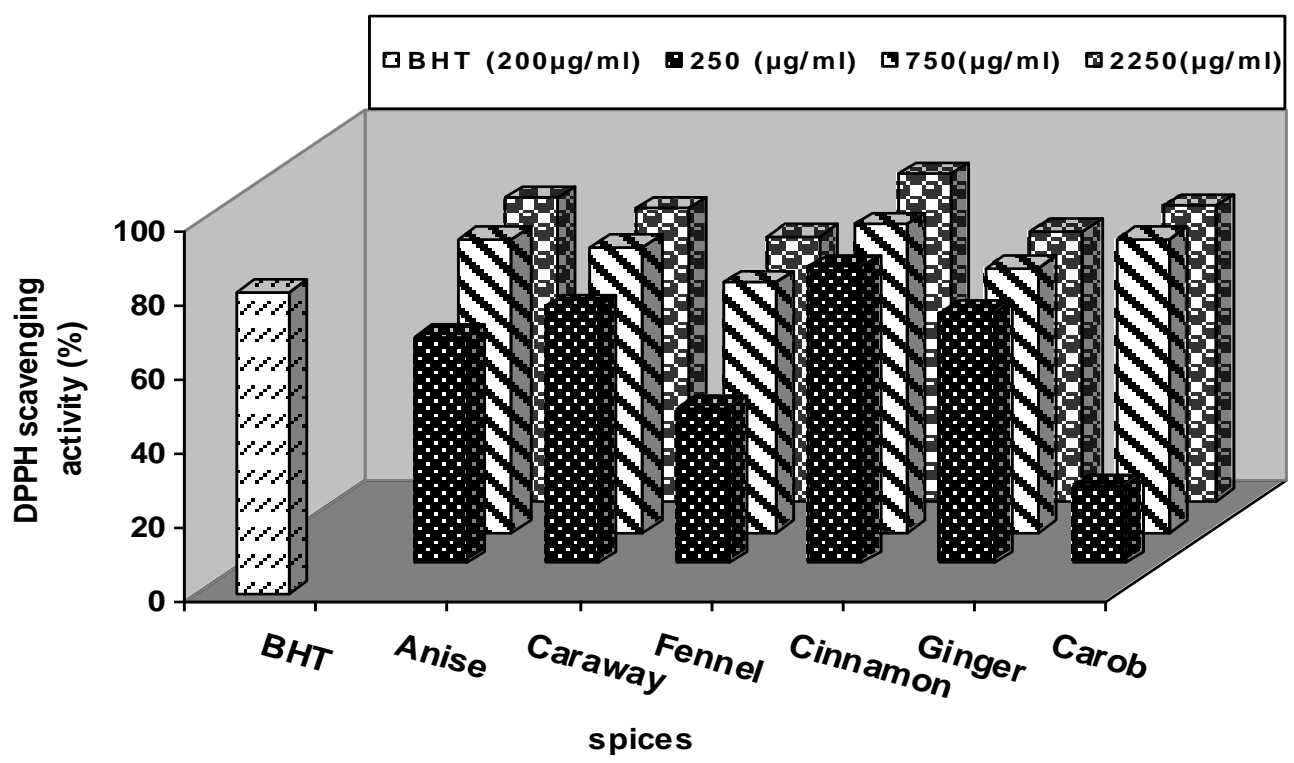

Figure 2. DPPH scavenging activity (\%) of different concentrations of tested spices 
$250 \mu \mathrm{g} / \mathrm{gm}$. These results are in harmony with those of Gulcin, et al 2003) who found that the scavenging effect of water extracts of anise on the DPPH radical decrased which $64.07 \%$. Su, et al (2007) mentioned that cinnamon had the greatest capacity to quench DPPH, while black peppercorn had the least ability to quench DPPH.

\subsection{Linolic acid emulsion test}

The antioxidant activity of different concentrations of tested spices in the linoleic acid emulsion is shown in Fig. (3). Antioxidant activity was determined by the decrease in its absorbance at $234 \mathrm{~nm}$, which induced by antioxidant. Increasing the concentration of spices tested up to $100 \mu \mathrm{g} / \mathrm{gm}$ emulsion resulted an increase in antioxidant in all samples.

Generally all the concentrations of tested spices recorded higher antioxidant activity compared with BHT. Cinnamon showed the highest antioxidant activity at all concentration followed by anise, carob and ginger. While fennel and caraway recorded closely antioxidant activity which was at the least position. These results are in agreement with those obtained by Gulcin et al (2003). Who found that the antioxidant activity of anise extract increased with increasing concentration.

\section{Total phenolics content of tested spices}

Phenol are very important plant constituents because of their radical scavenging ability due to their hydroxyl group. (Gulcin, et al 2003). Typical phenolics that possess antioxidant activity are known to be mainly phenolic acid and flavonoids. Phenolic acid are a major class of phenolic compounds, widely occurring in the fruits, vegetable and spices (Wojdylo, et al 2007

The amount of total phenolic in tested spices are given in Fig. (4). The amount of total phenolics, measured by Folin-Cio-Calteu method varied in some spices under this study and ranged from 11.19 to $22.95 \mathrm{mg}$ gallic acid/gm dry extract. Caraway had the highest levels of total phenolics followed by fennel then cinnamon and anise being 22.95, 21.2719 .83 and $19.7 \mathrm{mg}$ as gallic acid/gm dry extract, while carob had the lowest one of total phenolics (11.19 mg gallic acid/gm dry extract). Different results were reported in this aspect whereas some authors found correlation between the polyphenol content and the antioxidant activity, others found no such relationship. (Moure et al 2001).

\section{Application of tested spices in food products}

\subsection{Croissant}

\subsubsection{Selection of best concentration of test- ed spices}

Statistical analysis of panelist scores for sensory properties of croissant containing different concentrations of tested spices were evaluated to choice their best concentration. The received scores of croissant containing different concentrations of tested spices were statistically analyzed using Duncan's multiple range test and the results are given in Table (1).

No significant difference was observed in all sensory properties of croissant containing $1.0 \%$, $1.5 \%$ anise, caraway, fennel or cinnamon as well as $1.5,2.5 \%$ ginger and $1.0 \%$ carob compared to control. It was noticed that the addition of more than $1.5 \%$ of each of anise, caraway, fennel or cinnamon and more than $1.0 \%$ carob reduced all the sensory properties of croissant. Meanwhile, the increasing the concentration of ginger up to $2.5 \%$, the increasing the acceptability and mean score values of croissant. Therefore, a concentration of $1.5 \%$ of anise, caraway fennel and cinnamon was chosen to test their effectiveness against oxidation of lipid in croissant while the chosen concentration of ginger was $2.5 \%$ and carob was $1 \%$.

\subsubsection{Moisture content of croissant during storage}

The moisture content of croissant containing tested spices during storage at room temperature are given in Table (2). Moisture content of croissant ranged between $19.67 \% \pm 0.39$ in fennel croissant to $23.30 \% \pm 0.51$ for ginger croissant at zero time. During storage, the moisture content of all samples gradually decreased, it reached a values ranging $13.72 \% \pm 0.25$ for control to $18.14 \%$ \pm 0.15 in cinnamon croissant after 14 days. The highest losses in moisture content of croissant were observed for control samples and BHT.

\subsubsection{Measurements of lipid oxidation}

\subsubsection{Peroxide value (PV)}

The primary products of lipid peroxidation are hydroperoxidations. Therefore, determining the concentration of peroxides is one clear index of lipid peroxidation. Changes occurring in PV values in extracted lipids from croissant containing 


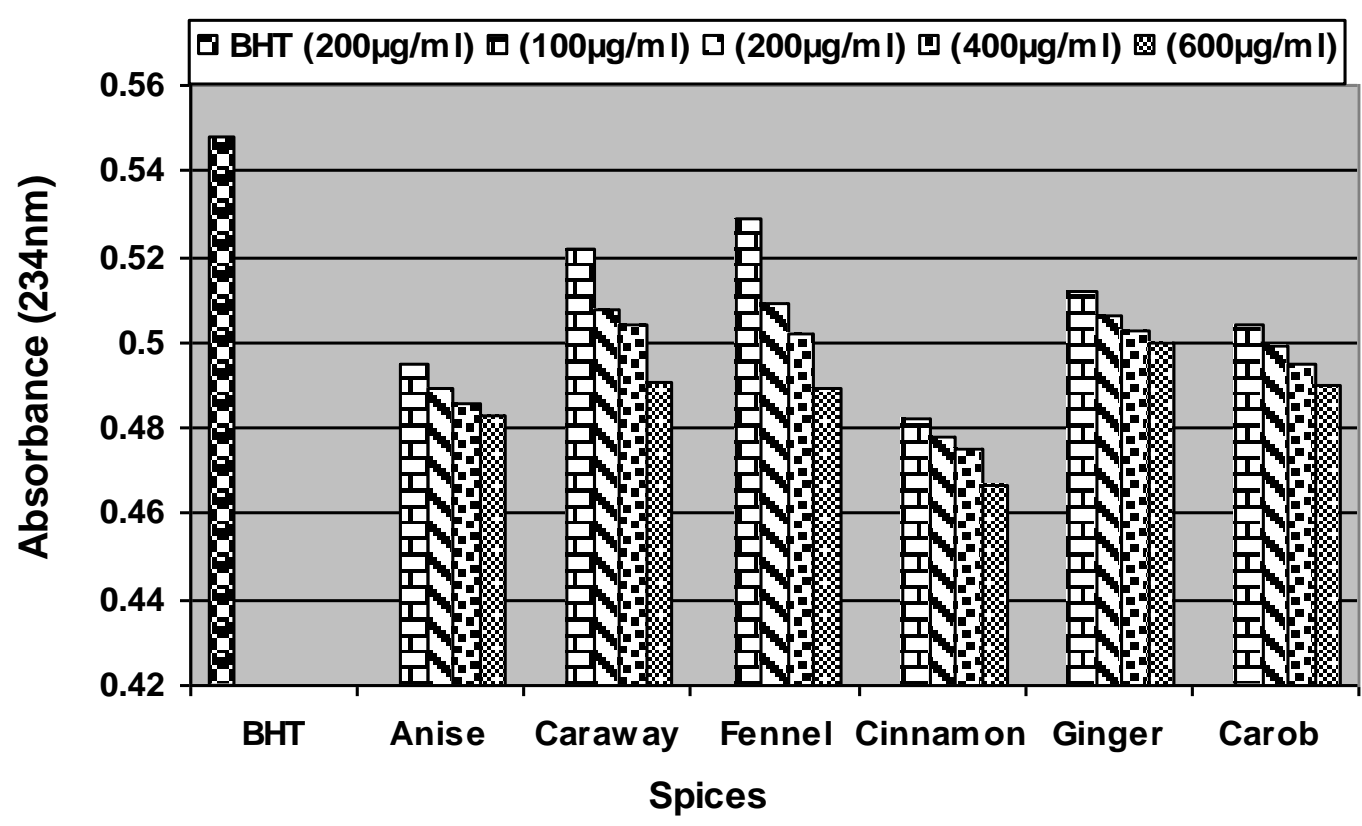

Figure 3. Antioxidant activity of different concentrations of tested spices in the linoleic acid emulsion

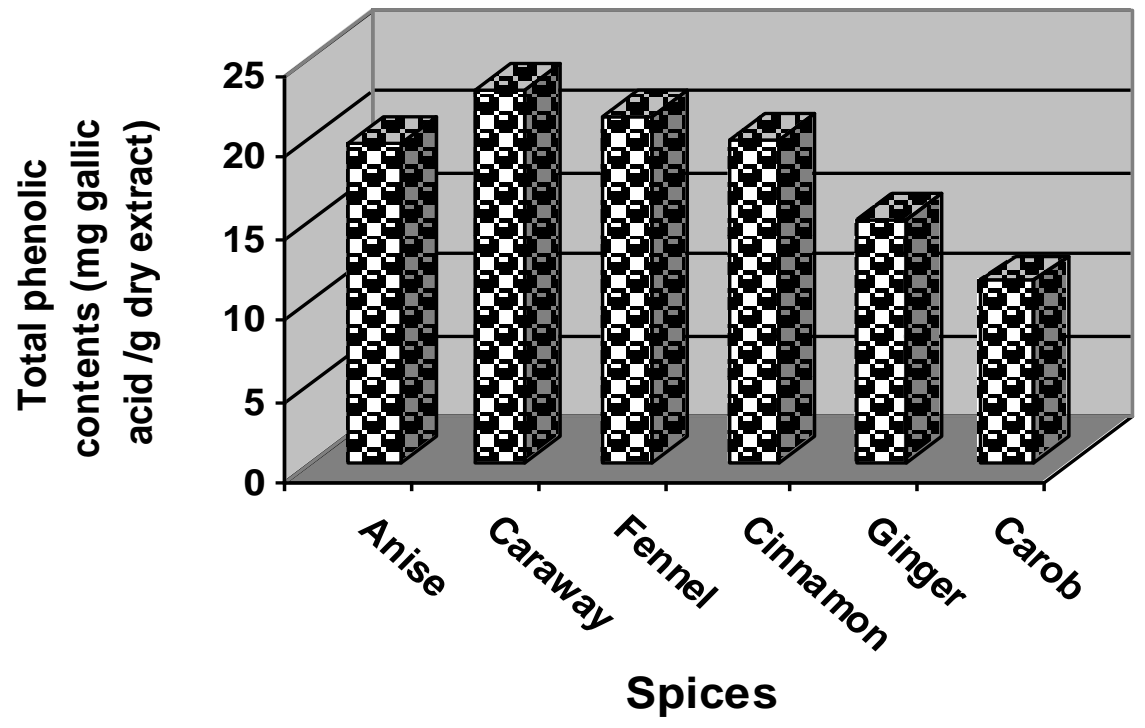

Figure 4. Total phenolic contents of the tested spices 
Table 1. Statistical analysis of scores of sensory properties of croissant containing different concentration of some spices

\begin{tabular}{|c|c|c|c|c|c|c|}
\hline \multirow[b]{2}{*}{ Conc. $(\%)$} & \multicolumn{6}{|c|}{ Means* of scores of sensory properties } \\
\hline & Texture & Crust color & Crumb color & Odor & Taste & $\begin{array}{c}\text { Overall } \\
\text { acceptability }\end{array}$ \\
\hline \multicolumn{7}{|c|}{ Anise } \\
\hline Zero & $8.6^{\mathrm{A}}$ & $8.5^{\mathrm{A}}$ & $7.9^{\mathrm{A}}$ & $7.8^{\mathrm{A}}$ & $8.0^{\mathrm{A}}$ & $7.8^{\mathrm{A}}$ \\
\hline 1.0 & $8.4^{\mathrm{A}}$ & $8.3^{\mathrm{A}}$ & $8.0^{\mathrm{A}}$ & $7.7^{\mathrm{A}}$ & $7.8^{\mathrm{A}}$ & $7.7^{\mathrm{A}}$ \\
\hline 1.5 & $7.9^{\mathrm{A}}$ & $8.2^{\mathrm{A}}$ & $8.2^{\mathrm{A}}$ & $8.2^{\mathrm{A}}$ & $8.3^{\mathrm{A}}$ & $8.1^{\mathrm{A}}$ \\
\hline 2.5 & $6.9^{\mathrm{B}}$ & $6.7^{\mathrm{B}}$ & $6.4^{\mathrm{B}}$ & $6.2^{\mathrm{B}}$ & $6.4^{\mathrm{B}}$ & $5.9^{\mathrm{B}}$ \\
\hline \multicolumn{7}{|c|}{ Caraway } \\
\hline Zero & $8.6^{\mathrm{A}}$ & $8.5^{\mathrm{A}}$ & $7.9^{\mathrm{A}}$ & $7.8^{\mathrm{A}}$ & $8.0^{\mathrm{A}}$ & $7.8^{\mathrm{A}}$ \\
\hline 1.0 & $7.5^{\mathrm{B}}$ & $8.1^{\mathrm{A}}$ & $7.8^{\mathrm{AB}}$ & $8.0^{\mathrm{A}}$ & $7.9^{\mathrm{A}}$ & $8.2^{\mathrm{A}}$ \\
\hline 1.5 & $7.9^{\mathrm{AB}}$ & $7.9^{\mathrm{AB}}$ & $7.8^{\mathrm{AB}}$ & $7.6^{\mathrm{AB}}$ & $8.0^{\mathrm{A}}$ & $8.2^{\mathrm{A}}$ \\
\hline 2.5 & $7.3^{\mathrm{B}}$ & $7.1^{\mathrm{B}}$ & $6.9^{\mathrm{B}}$ & $6.7^{\mathrm{B}}$ & $6.6^{\mathrm{B}}$ & $6.7^{\mathrm{B}}$ \\
\hline \multicolumn{7}{|c|}{ Fennel } \\
\hline Zero & $8.6^{\mathrm{A}}$ & $8.5^{\mathrm{A}}$ & $7.9^{\mathrm{B}}$ & $7.8^{\mathrm{A}}$ & $8.0^{\mathrm{BC}}$ & $7.8^{\mathrm{BC}}$ \\
\hline 1.0 & $8.3^{\mathrm{A}}$ & $8.4^{\mathrm{A}}$ & $8.3^{\mathrm{AB}}$ & $8.5^{\mathrm{A}}$ & $8.2^{\mathrm{AB}}$ & $8.4^{\mathrm{AB}}$ \\
\hline 1.5 & $8.6^{\mathrm{A}}$ & $8.6^{\mathrm{A}}$ & $8.6^{\mathrm{A}}$ & $8.5^{\mathrm{A}}$ & $8.8^{\mathrm{A}}$ & $8.7^{\mathrm{A}}$ \\
\hline 2.5 & $7.7^{\mathrm{B}}$ & $7.5^{\mathrm{B}}$ & $7.7^{\mathrm{B}}$ & $7.9^{\mathrm{A}}$ & $7.4^{\mathrm{C}}$ & $7.3^{\mathrm{C}}$ \\
\hline \multicolumn{7}{|c|}{ Cinnamon } \\
\hline Zero & $8.6^{\mathrm{A}}$ & $8.5^{\mathrm{A}}$ & $7.9^{\mathrm{A}}$ & $7.8^{\mathrm{B}}$ & $8.0^{\mathrm{A}}$ & $7.8^{\mathrm{B}}$ \\
\hline 1.0 & $8.5^{\mathrm{A}}$ & $8.4^{\mathrm{A}}$ & $8.4^{\mathrm{A}}$ & $8.4^{\mathrm{AB}}$ & $8.3^{\mathrm{A}}$ & $8.4^{\mathrm{A}}$ \\
\hline 1.5 & $8.1^{\mathrm{A}}$ & $8.3^{\mathrm{A}}$ & $8.0^{\mathrm{A}}$ & $8.5^{\mathrm{A}}$ & $8.6^{\mathrm{A}}$ & $8.6^{\mathrm{A}}$ \\
\hline 2.5 & $7.5^{\mathrm{B}}$ & $7.2^{\mathrm{B}}$ & $6.2^{\mathrm{B}}$ & $6.8^{\mathrm{C}}$ & $6.9^{\mathrm{B}}$ & $6.9^{\mathrm{C}}$ \\
\hline \multicolumn{7}{|c|}{ Ginger } \\
\hline Zero & $8.6^{\mathrm{A}}$ & $8.5^{\mathrm{A}}$ & $7.9^{\mathrm{B}}$ & $7.8^{\mathrm{AB}}$ & $8.0^{\mathrm{AB}}$ & $7.8^{\mathrm{AB}}$ \\
\hline 1.0 & $7.9^{\mathrm{B}}$ & $7.8^{\mathrm{B}}$ & $7.7^{\mathrm{B}}$ & $7.4^{\mathrm{B}}$ & $7.4^{\mathrm{B}}$ & $7.2^{\mathrm{B}}$ \\
\hline 1.5 & $8.2^{\mathrm{AB}}$ & $8.3^{\mathrm{AB}}$ & $8.0^{\mathrm{AB}}$ & $8.1^{\mathrm{AB}}$ & $7.8^{\mathrm{AB}}$ & $8.3^{\mathrm{A}}$ \\
\hline 2.5 & $8.5^{\mathrm{A}}$ & $8.4^{\mathrm{AB}}$ & $8.6^{\mathrm{A}}$ & $8.3^{\mathrm{A}}$ & $8.4^{\mathrm{A}}$ & $8.4^{\mathrm{A}}$ \\
\hline \multicolumn{7}{|c|}{ Carob } \\
\hline Zero & $8.6^{\mathrm{A}}$ & $8.5^{\mathrm{A}}$ & $7.9^{\mathrm{A}}$ & $7.8^{\mathrm{AB}}$ & $8.0^{\mathrm{A}}$ & $7.8^{\mathrm{AB}}$ \\
\hline 1.0 & $7.8^{\mathrm{AB}}$ & $8.0^{\mathrm{AB}}$ & $7.7^{\mathrm{A}}$ & $8.2^{\mathrm{A}}$ & $8.2^{\mathrm{A}}$ & $8.3^{\mathrm{A}}$ \\
\hline 1.5 & $7.5^{\mathrm{BC}}$ & $7.5^{\mathrm{BC}}$ & $7.0^{\mathrm{B}}$ & $7.4^{\mathrm{BC}}$ & $7.0^{\mathrm{B}}$ & $7.1^{\mathrm{B}}$ \\
\hline 2.5 & $6.7^{\mathrm{C}}$ & $7.0^{\mathrm{C}}$ & $7.0^{\mathrm{B}}$ & $6.9^{\mathrm{C}}$ & $6.2^{\mathrm{C}}$ & $6.2^{\mathrm{C}}$ \\
\hline
\end{tabular}

*: Means in a columns showing the same letter are not significantly different $(\mathrm{p}>0.05)$ 
Table 2. Moisture content (\%) of croissant containing tested spices during storage at room temperature

\begin{tabular}{|c|c|c|c|c|c|}
\hline \multirow{2}{*}{ Spices } & \multicolumn{5}{|c|}{ Moisture content $(\%)$ during storage periods ( days) } \\
\cline { 2 - 6 } & Zero & 2 & 6 & 10 & 14 \\
\hline Control & $20.27 \pm 0.34$ & $18.97 \pm 0.22$ & $18.37 \pm 0.03$ & $16.19 \pm 0.13$ & $13.72 \pm 0.25$ \\
\hline BHT & $20.18 \pm 0.14$ & $18.57 \pm 0.19$ & $17.8 \pm 0.17$ & $15.61 \pm 0.22$ & $15.96 \pm 0.03$ \\
\hline Anise & $20.82 \pm 0.51$ & $17.84 \pm 0.39$ & $18.35 \pm 0.14$ & $17.28 \pm 0.28$ & $17.01 \pm 0.10$ \\
\hline Caraway & $20.49 \pm 0.55$ & $19.35 \pm 0.12$ & $16.87 \pm 0.07$ & $16.18 \pm 0.10$ & $16.08 \pm 0.09$ \\
\hline Fennel & $19.67 \pm 0.39$ & $18.77 \pm 0.32$ & $16.44 \pm 0.02$ & $16.06 \pm 0.02$ & $15.97 \pm 0.08$ \\
\hline Cinnamon & $21.52 \pm 0.56$ & $20.19 \pm 0.29$ & $18.22 \pm 0.41$ & $18.18 \pm 0.25$ & $18.14 \pm 0.15$ \\
\hline Ginger & $22.30 \pm 0.51$ & $17.88 \pm 0.10$ & $17.62 \pm 0.19$ & $16.80 \pm 0.13$ & $16.04 \pm 0.19$ \\
\hline Carob & $21.79 \pm 0.62$ & $19.70 \pm 0.05$ & $18.80 \pm 0.06$ & $16.29 \pm 0.35$ & $16.12 \pm 0.20$ \\
\hline
\end{tabular}

Data expressed as mean of 3 replicates \pm standard deviation

the chosen concentrations of tested spices during storage at room temperature are given in Fig. (5). All The six natural antioxidant used and BHT were slowed down the rate of peroxide formation. The PV of all samples which contained synthetic antioxidant (BHT) or natural antioxidants were lower than that of control sample during storage for 14 days of storage at room temperature. Croissant which contained the tested spices showed lower PV ranged from 2.3 to $3.5 \mathrm{meq} / \mathrm{kg}$ oil, compared to $5 \mathrm{meq} / \mathrm{kg}$ oil of control after 14 days of storage. These results are in agreement with those of Lean and Mohamed, (1999).

\subsubsection{Acid value (AV)}

The acid value of croissant containing the best chosen concentrations of tested spices during storage at room temperature is summarized in Fig. (6). An increase in AV was observed in all croissant samples during storage. The increase was considerably higher in control sample compared to croissant containing the tested spices. After 14 days of storage the values were $3.13,1.63$ and 1.13 for control sample, BHT and carob respectively, while the $\mathrm{AV}$ of other samples ranged between 1.25 to 2.53.These result are accordance with those of Reddy, et al (2005).

\subsubsection{Sensory evaluation of croissant during storage}

The sensory evaluation of croissant appears to be necessary since the addition of natural antioxi- dants, and BHT increased shelf life of product by. For these reasons, a questionnaire was conducted to detect the acceptability of croissant samples. The sensory properties of croissant containing the best concentration of the tested spices during storage at room temperature are given in Table (3). Croissant containing cinnamon, caraway and fennel showed significantly superior overall acceptability than control and other samples after 14 days. The minimum reduction in overall acceptability was observed after 6 days in croissant containing BHT and control samples. It can be noticed that croissant containing cinnamon, caraway, fennel and carob were comparable to those sample containing BHT and control sample being able to maintain the quality of croissant during storage for 14 days.

\subsection{Filling cream}

\subsubsection{Selection of best concentration of test- ed spices}

Statistical analysis of panelist scores for sensory properties of filling cream containing different concentration of tested spices were statistically analyzed to choice the best concentration of spices and the results are given in Table (4).

It was observes that with increasing the addition level of anise, fennel, ginger and carob up to $2 \%$, the sensory properties improved and received the highest score values. Concerning caraway and cinnamon, the panelist prefer the filling cream 


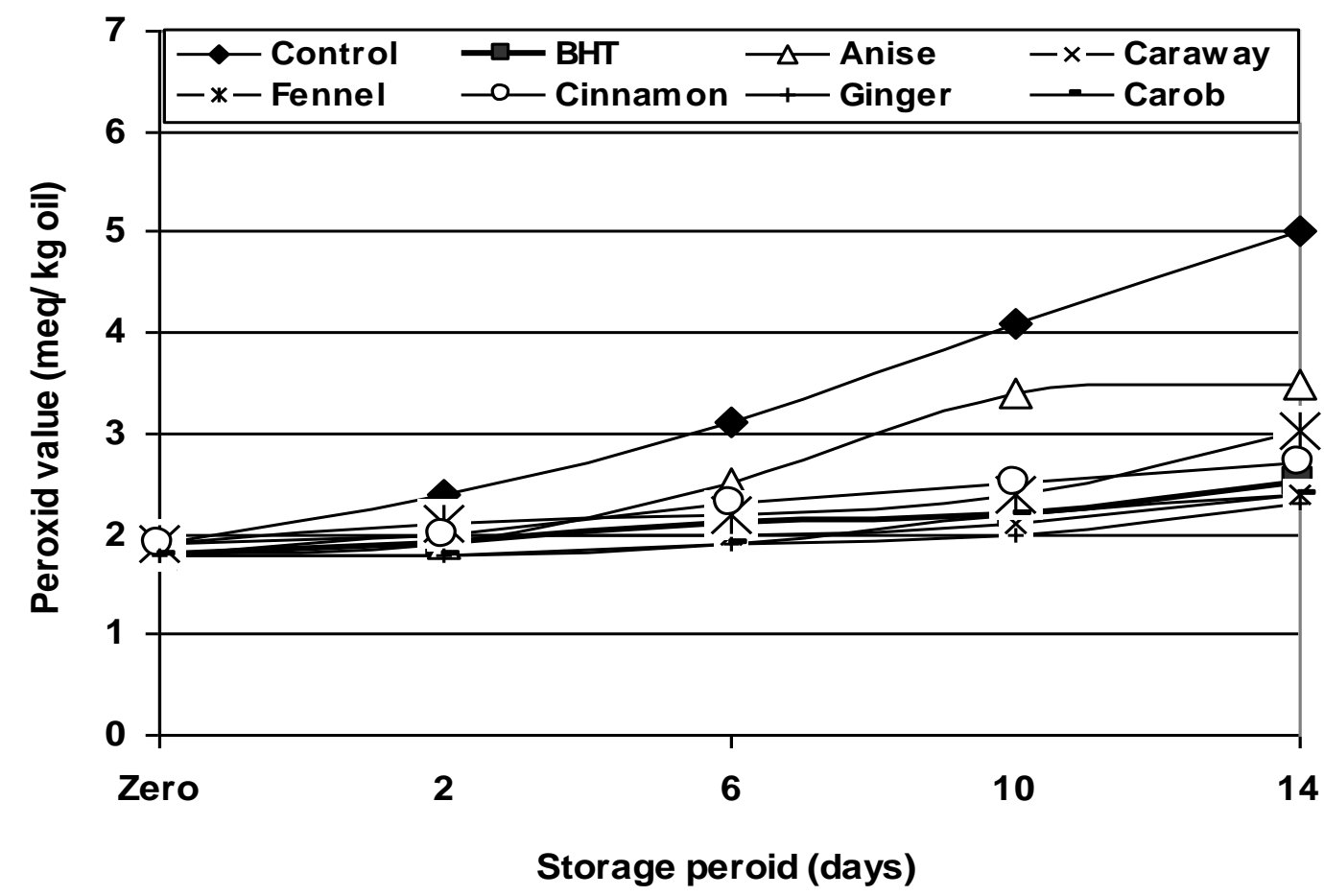

Figure 5. Peroxide value of croissant containing tested spices during storage at room temperature

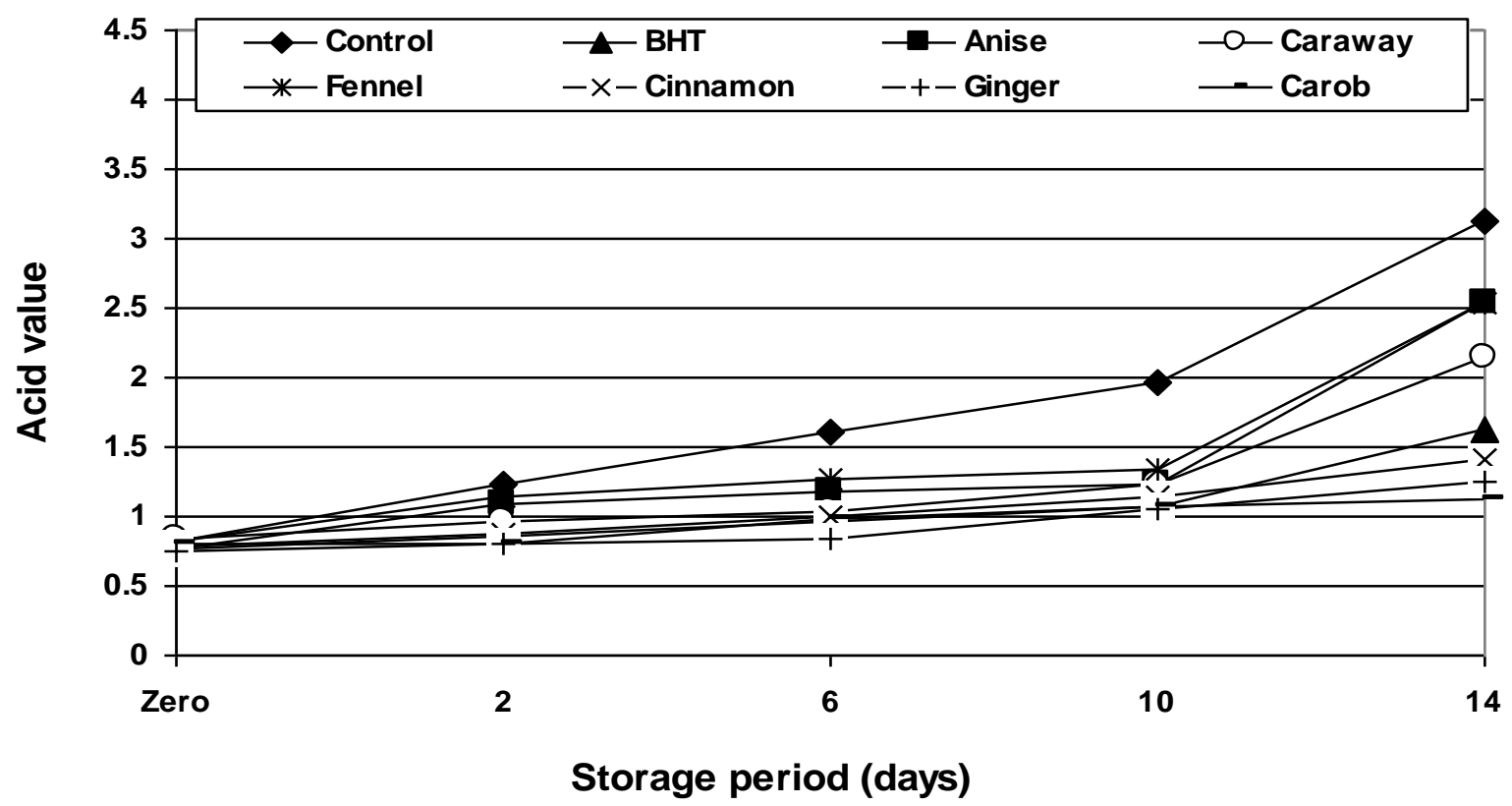

Figure 6. Acid value of croissant containing different spices during storage at room temperature 
Table 3. Statistical analysis of scores of sensory properties of croissant containing tested spices during storage at room temperature*

\begin{tabular}{|c|c|c|c|c|c|c|c|c|}
\hline \multirow{2}{*}{$\begin{array}{l}\text { Storage } \\
\text { periods } \\
\text { (days) }\end{array}$} & \multicolumn{8}{|c|}{ Croissant containing } \\
\hline & $\begin{array}{c}\text { Control } \\
\text { (zero) }\end{array}$ & $\begin{array}{c}\text { BHT } \\
(0.02 \%)\end{array}$ & $\begin{array}{c}\text { Anise } \\
(1.5 \%)\end{array}$ & $\begin{array}{c}\text { Caraway } \\
(1.5 \%)\end{array}$ & $\begin{array}{l}\text { Fennel } \\
(1.5 \%)\end{array}$ & $\begin{array}{c}\text { Cinnamon } \\
(1.5 \%)\end{array}$ & $\begin{array}{l}\text { Ginger } \\
(2.5 \%)\end{array}$ & $\begin{array}{c}\text { Carob } \\
(1.0 \%)\end{array}$ \\
\hline \multicolumn{9}{|c|}{ Texture } \\
\hline Zero & $8.6^{\mathrm{Aa}}$ & $8.5^{\mathrm{ABa}}$ & $7.9^{\mathrm{BCa}}$ & $7.9^{\mathrm{BCa}}$ & $8.6^{\mathrm{Aa}}$ & $8.1^{\mathrm{ABCa}}$ & $8.6^{\mathrm{Aa}}$ & $7.8^{\mathrm{Ca}}$ \\
\hline 2 & $8.4^{\mathrm{ABa}}$ & $8.6^{\mathrm{Aa}}$ & $7.7^{\mathrm{CDab}}$ & $8.0^{\mathrm{BCDa}}$ & $8.6^{\mathrm{Aa}}$ & $8.2^{\mathrm{ABCa}}$ & $8.6^{\mathrm{ABa}}$ & $7.6^{\mathrm{Dab}}$ \\
\hline 6 & $6.2^{\mathrm{Eb}}$ & $6.7^{\text {Deb }}$ & $7.1^{\mathrm{CDbc}}$ & $6.8^{\mathrm{Db}}$ & $7.5^{\mathrm{BCb}}$ & $7.4^{\mathrm{BCb}}$ & $8.4^{\mathrm{Aa}}$ & $7.7^{\mathrm{Ba}}$ \\
\hline 10 & $5.5^{\mathrm{Dc}}$ & $5.5^{\mathrm{Dc}}$ & $6.5^{\mathrm{Ccd}}$ & $6.8^{\mathrm{BCb}}$ & $6.5^{\mathrm{Cc}}$ & $7.4^{\mathrm{Ab}}$ & $7.4^{\mathrm{Ab}}$ & $7.1^{\mathrm{ABbc}}$ \\
\hline 14 & $4.4^{\mathrm{Ed}}$ & $5.5^{\mathrm{Dc}}$ & $5.9^{\mathrm{CDd}}$ & $6.6^{\mathrm{Bb}}$ & $6.3^{\mathrm{BCc}}$ & $6.7^{\mathrm{Bc}}$ & $7.2^{\mathrm{Ab}}$ & $6.6^{\mathrm{Bc}}$ \\
\hline \multicolumn{9}{|c|}{ Crust color } \\
\hline Zero & $8.4^{\mathrm{ABa}}$ & $8.5^{\mathrm{ABa}}$ & $8.2^{\mathrm{ABa}}$ & $7.9^{\mathrm{Ba}}$ & $8.6^{\mathrm{Aa}}$ & $8.3^{\mathrm{AB} a}$ & $8.4^{\mathrm{ABa}}$ & $8.0^{\mathrm{ABa}}$ \\
\hline 2 & $8.4^{\mathrm{ABa}}$ & $8.5^{\mathrm{Aa}}$ & $8.3^{\mathrm{ABa}}$ & $8.0^{\mathrm{ABa}}$ & $8.3^{\mathrm{ABa}}$ & $8.0^{\mathrm{ABa}}$ & $8.4^{\mathrm{ABa}}$ & $7.9^{\mathrm{Ba}}$ \\
\hline 6 & $7.5^{\mathrm{Ab}}$ & $6.7^{\mathrm{CDb}}$ & $7.4^{\mathrm{ABb}}$ & $6.9^{\mathrm{BCDb}}$ & $7.6^{\mathrm{Ab}}$ & $6.6^{\mathrm{Db}}$ & $7.3^{\mathrm{ABCb}}$ & $7.3^{\mathrm{ABb}}$ \\
\hline 10 & $7.2^{\mathrm{Ab}}$ & $6.5^{\mathrm{Bb}}$ & $6.6^{\mathrm{Bbc}}$ & $7.2^{\mathrm{Ab}}$ & $7.3^{\mathrm{Abc}}$ & $6.9^{\mathrm{ABb}}$ & $7.3^{\mathrm{Ab}}$ & $7.3^{\mathrm{Ab}}$ \\
\hline 14 & $6.4^{\mathrm{Cc}}$ & $6.4^{\mathrm{Cb}}$ & $7.0^{\mathrm{Ac}}$ & $6.8^{\mathrm{ABb}}$ & $7.1^{\mathrm{Ac}}$ & $6.6^{\mathrm{BCb}}$ & 7. $0^{\mathrm{Ab}}$ & $7.0^{\mathrm{Ab}}$ \\
\hline \multicolumn{9}{|c|}{ Crumb color } \\
\hline Zero & $7.9^{\mathrm{BCa}}$ & $8.8^{\mathrm{Aa}}$ & $8.3^{\mathrm{ABa}}$ & $7.8^{\mathrm{BCab}}$ & $8.6^{\mathrm{Aa}}$ & $8.0^{\mathrm{BCa}}$ & $8.6^{\mathrm{Aa}}$ & $7.7^{\mathrm{Ca}}$ \\
\hline 2 & $8.0^{\mathrm{Ca}}$ & $8.7^{\mathrm{Aa}}$ & $8.0^{\mathrm{Ca}}$ & $7.9^{\mathrm{Ca}}$ & $8.6^{\mathrm{ABa}}$ & $8.2^{\mathrm{ABCa}}$ & $8.1^{\mathrm{BCa}}$ & $7.8^{\mathrm{Ca}}$ \\
\hline 6 & $7.0^{\mathrm{Bbc}}$ & $7.1^{\mathrm{ABb}}$ & $7.4^{\mathrm{ABb}}$ & $7.3^{\mathrm{ABbc}}$ & $7.5^{\mathrm{Ab}}$ & $6.4^{\mathrm{Cb}}$ & $7.3^{\mathrm{ABb}}$ & $7.3^{\mathrm{ABab}}$ \\
\hline 10 & $7.2^{\mathrm{Ab}}$ & $6.4^{\mathrm{Bc}}$ & $6.7^{\mathrm{ABc}}$ & $7.0^{\mathrm{Adc}}$ & $7.2^{\mathrm{Ab}}$ & $6.8^{\mathrm{ABb}}$ & $6.9^{\mathrm{ABb}}$ & $6.9^{\mathrm{ABb}}$ \\
\hline 14 & $6.6^{\mathrm{BCc}}$ & $6.3^{\mathrm{Cc}}$ & $6.7^{\mathrm{BCc}}$ & $6.6^{\mathrm{BCd}}$ & $7.3^{\mathrm{Ab}}$ & $6.6^{\mathrm{BCb}}$ & $7.3^{\mathrm{Ab}}$ & $7.0^{\mathrm{ABb}}$ \\
\hline \multicolumn{9}{|c|}{ Odor } \\
\hline Zero & $7.9^{\mathrm{ABa}}$ & $7.7^{\mathrm{Ba}}$ & $8.2^{\mathrm{ABa}}$ & $7.6^{\mathrm{Ba}}$ & $8.5^{\mathrm{Aa}}$ & $8.5^{\mathrm{Aa}}$ & $8.3^{\mathrm{ABa}}$ & $8.2^{\mathrm{ABa}}$ \\
\hline 2 & $7.8^{\mathrm{BCa}}$ & $7.9^{\mathrm{BCa}}$ & $7.9^{\mathrm{BCab}}$ & $7.6^{\mathrm{Ca}}$ & $8.3^{\mathrm{ABa}}$ & $8.5^{\mathrm{Aa}}$ & $7.9^{\mathrm{BCab}}$ & $7.9^{\mathrm{BCab}}$ \\
\hline 6 & $6.3^{\mathrm{Db}}$ & $6.8^{\mathrm{Cb}}$ & $7.6^{\mathrm{Bb}}$ & $7.5^{\mathrm{Ba}}$ & $7.3^{\mathrm{Bb}}$ & $8.4^{\mathrm{Aa}}$ & $7.7^{\mathrm{Bab}}$ & $7.4^{\mathrm{Bbc}}$ \\
\hline 10 & $5.6^{\mathrm{Ec}}$ & $6.6^{\mathrm{Db}}$ & $6.6^{\mathrm{Dc}}$ & $7.5^{\mathrm{ABa}}$ & $7.1^{\mathrm{BCDb}}$ & $7.7^{\mathrm{Ab}}$ & $7.3^{\mathrm{ABCb}}$ & $6.9^{\mathrm{CDcd}}$ \\
\hline 14 & $5.0^{\mathrm{Dd}}$ & $5.5^{\mathrm{Cc}}$ & $6.7^{\mathrm{Bc}}$ & $7.4^{\mathrm{Aa}}$ & $7.2^{\mathrm{Ab}}$ & $7.5^{\mathrm{Ab}}$ & $6.4^{\mathrm{Bc}}$ & $6.6^{\mathrm{Bd}}$ \\
\hline \multicolumn{9}{|c|}{ Taste } \\
\hline Zero & $8.0^{\mathrm{BCa}}$ & $7.6^{\mathrm{Ca}}$ & $8.3^{\mathrm{Aa}}$ & $8.0^{\mathrm{BCab}}$ & $8.8^{\mathrm{Aa}}$ & $8.5^{\mathrm{ABa}}$ & $8.4^{\mathrm{ABa}}$ & $8.2^{\mathrm{ABCab}}$ \\
\hline 2 & $8.0^{\mathrm{ABa}}$ & $7.7^{\mathrm{Ca}}$ & $8.1^{\mathrm{ABa}}$ & $8.1^{\mathrm{ABa}}$ & $8.4^{\mathrm{Aa}}$ & $8.6^{\mathrm{Aa}}$ & $8.1^{\mathrm{ABab}}$ & $8.4^{\mathrm{Aa}}$ \\
\hline 6 & $6.1^{\mathrm{Cb}}$ & $6.4^{\mathrm{Cb}}$ & $7.4^{\mathrm{Bb}}$ & $7.4^{\mathrm{Bb}}$ & $7.4^{\mathrm{Bb}}$ & $8.4^{\mathrm{Aa}}$ & $7.7^{\mathrm{Bbc}}$ & $7.6^{\mathrm{Bbc}}$ \\
\hline 10 & $5.6^{\mathrm{Db}}$ & $6.6^{\mathrm{Cb}}$ & $6.7^{\mathrm{Cc}}$ & $7.5^{\mathrm{ABab}}$ & $7.3^{\mathrm{ABb}}$ & $7.6^{\mathrm{Ab}}$ & $7.3^{\mathrm{ABc}}$ & $7.0^{\mathrm{BCcd}}$ \\
\hline 14 & $6.0^{\mathrm{CDb}}$ & $5.6^{\mathrm{Dc}}$ & $6.7^{\mathrm{Bc}}$ & $7.4^{\mathrm{Ab}}$ & $7.2^{\mathrm{Ab}}$ & $7.4^{\mathrm{Ab}}$ & $6.4^{\mathrm{BCd}}$ & $6.6^{\mathrm{Bd}}$ \\
\hline \multicolumn{9}{|c|}{ Overall acceptability } \\
\hline Zero & $7.8^{\mathrm{Ba}}$ & $8.3^{\mathrm{ABa}}$ & $8.1^{\mathrm{ABa}}$ & $8.2^{\mathrm{ABa}}$ & $8.7^{\mathrm{Aa}}$ & $8.6^{\mathrm{Aa}}$ & $8.4^{\mathrm{ABa}}$ & $8.4^{\mathrm{ABa}}$ \\
\hline 2 & $8.0^{\mathrm{A} \mathrm{a}}$ & $8.2^{\mathrm{Aa}}$ & $8.0^{\mathrm{Aa}}$ & $8.3^{\mathrm{Aa}}$ & $8.6^{\mathrm{Aa}}$ & $8.5^{\mathrm{Aa}}$ & $8.2^{\mathrm{Aa}}$ & $8.1^{\mathrm{Aa}}$ \\
\hline 6 & $6.3^{\mathrm{Cb}}$ & $6.7^{\mathrm{Cb}}$ & $7.3^{\mathrm{Bb}}$ & $7.5^{\mathrm{Bb}}$ & $7.6^{\mathrm{Bb}}$ & $8.2^{\text {Aab }}$ & $7.4^{\mathrm{Bb}}$ & $7.6^{\mathrm{Bb}}$ \\
\hline 10 & $6.1^{\mathrm{Dbc}}$ & $6.4^{\mathrm{Db}}$ & $7.2^{\mathrm{BCb}}$ & $7.4^{\mathrm{BCb}}$ & $7.1^{\mathrm{Cc}}$ & $8.0^{\mathrm{Ab}}$ & $7.5^{\mathrm{Bb}}$ & $7.2^{\mathrm{BCbc}}$ \\
\hline 14 & $5.6^{\mathrm{Cc}}$ & $5.8^{\mathrm{Cc}}$ & $6.7^{\mathrm{Bb}}$ & $7.4^{\mathrm{Ab}}$ & $7.2^{\mathrm{Abc}}$ & $7.3^{\mathrm{Ac}}$ & $6.7^{\mathrm{Bc}}$ & $7.0^{\mathrm{ABc}}$ \\
\hline
\end{tabular}

*Means in a row showing the same capital letters are not significantly different $(p>0.05)$

*Means in a column showing the same small letters are not significantly different $(\mathrm{p}>0.05)$ 
Table 4. Statistical analysis of scores of sensory properties of filling cream containing different concentration of some spices

\begin{tabular}{|c|c|c|c|c|c|}
\hline \multirow[b]{2}{*}{ Conc. $(\%)$} & \multicolumn{5}{|c|}{ Means* of scores of sensory properties } \\
\hline & Appearance & Color & Odor & Taste & $\begin{array}{c}\text { Overall } \\
\text { acceptability }\end{array}$ \\
\hline \multicolumn{6}{|c|}{ Anise } \\
\hline Zero & $8.7^{\mathrm{A}}$ & $8.7^{\mathrm{A}}$ & $8.4^{\mathrm{A}}$ & $8.3^{\mathrm{B}}$ & $8.6^{\mathrm{AB}}$ \\
\hline 0.5 & $8.3^{\mathrm{A}}$ & $8.2^{\mathrm{A}}$ & $7.7^{\mathrm{B}}$ & $8.0^{\mathrm{B}}$ & $8.1^{\mathrm{B}}$ \\
\hline 1 & $8.9^{\mathrm{A}}$ & $8.6^{\mathrm{A}}$ & $8.8^{\mathrm{A}}$ & $8.5^{\mathrm{AB}}$ & $8.7^{\mathrm{AB}}$ \\
\hline 2 & $8.4^{\mathrm{A}}$ & $8.5^{\mathrm{A}}$ & $8.6^{\mathrm{A}}$ & $9.0^{\mathrm{A}}$ & $8.9^{\mathrm{A}}$ \\
\hline \multicolumn{6}{|c|}{ Caraway } \\
\hline Zero & $8.7^{\mathrm{A}}$ & $8.7^{\mathrm{A}}$ & $8.4^{\mathrm{A}}$ & $8.3^{\mathrm{AB}}$ & $8.6^{\mathrm{A}}$ \\
\hline 0.5 & $8.4^{\mathrm{A}}$ & $8.6^{\mathrm{A}}$ & $7.6^{\mathrm{B}}$ & $7.7^{\mathrm{B}}$ & $7.7^{\mathrm{B}}$ \\
\hline 1 & $8.4^{\mathrm{A}}$ & $8.7^{\mathrm{A}}$ & $8.7^{\mathrm{A}}$ & $8.7^{\mathrm{A}}$ & $8.8^{\mathrm{A}}$ \\
\hline 2 & $7.5^{\mathrm{B}}$ & $7.3^{\mathrm{B}}$ & $7.0^{\mathrm{B}}$ & $6.8^{\mathrm{C}}$ & $6.6^{\mathrm{C}}$ \\
\hline \multicolumn{6}{|c|}{ Fennel } \\
\hline Zero & $8.7^{\mathrm{A}}$ & $8.7^{\mathrm{A}}$ & $8.4^{\mathrm{A}}$ & $8.3^{\mathrm{AB}}$ & $8.6^{\mathrm{A}}$ \\
\hline 0.5 & $8.2^{\mathrm{A}}$ & $8.3^{\mathrm{A}}$ & $7.9^{\mathrm{A}}$ & $7.4^{\mathrm{C}}$ & $7.2^{\mathrm{B}}$ \\
\hline 1 & $8.1^{\mathrm{A}}$ & $8.3^{\mathrm{A}}$ & $8.1^{\mathrm{A}}$ & $7.6^{\mathrm{BC}}$ & $7.5^{\mathrm{B}}$ \\
\hline 2 & $8.3^{\mathrm{A}}$ & $8.3^{\mathrm{A}}$ & $8.6^{\mathrm{A}}$ & $8.6^{\mathrm{A}}$ & $8.7^{\mathrm{A}}$ \\
\hline \multicolumn{6}{|c|}{ Cinnamon } \\
\hline Zero & $8.7^{\mathrm{A}}$ & $8.7^{\mathrm{A}}$ & $8.4^{\mathrm{A}}$ & $8.3^{\mathrm{A}}$ & $8.6^{\mathrm{A}}$ \\
\hline 0.5 & $8.3^{\mathrm{A}}$ & $8.1^{\mathrm{A}}$ & $8.4^{\mathrm{A}}$ & $8.4^{\mathrm{A}}$ & $8.4^{\mathrm{A}}$ \\
\hline 1 & $8.7^{\mathrm{A}}$ & $7.9^{\mathrm{A}}$ & $8.5^{\mathrm{A}}$ & $8.5^{\mathrm{A}}$ & $8.6^{\mathrm{A}}$ \\
\hline 2 & $7.1^{\mathrm{B}}$ & $6.3^{\mathrm{B}}$ & $6.6^{\mathrm{B}}$ & $6.9^{\mathrm{B}}$ & $6.9^{\mathrm{B}}$ \\
\hline \multicolumn{6}{|c|}{ Ginger } \\
\hline Zero & $8.7^{\mathrm{A}}$ & $8.7^{\mathrm{A}}$ & $8.4^{\mathrm{A}}$ & $8.3^{\mathrm{A}}$ & $8.6^{\mathrm{A}}$ \\
\hline 0.5 & $7.6^{\mathrm{B}}$ & $7.2^{\mathrm{C}}$ & $5.9^{\mathrm{B}}$ & $6.1^{\mathrm{B}}$ & $6.1^{\mathrm{C}}$ \\
\hline 1 & $7.8^{\mathrm{B}}$ & $7.6^{\mathrm{BC}}$ & $7.8^{\mathrm{A}}$ & $7.6^{\mathrm{A}}$ & $7.7^{\mathrm{B}}$ \\
\hline 2 & $8.2^{\mathrm{AB}}$ & $8.3^{\mathrm{AB}}$ & $7.9^{\mathrm{A}}$ & $8.3^{\mathrm{A}}$ & $8.2^{\mathrm{AB}}$ \\
\hline \multicolumn{6}{|c|}{ Carob } \\
\hline Zero & $8.7^{\mathrm{A}}$ & $8.7^{\mathrm{A}}$ & $8.4^{\mathrm{A}}$ & $8.3^{\mathrm{A}}$ & $8.6^{\mathrm{A}}$ \\
\hline 0.5 & $7.7^{\mathrm{B}}$ & $7.9^{\mathrm{B}}$ & $6.0^{\mathrm{C}}$ & $6.0^{\mathrm{C}}$ & $5.7^{\mathrm{C}}$ \\
\hline 1 & $7.4^{\mathrm{B}}$ & $7.7^{\mathrm{B}}$ & $7.2^{\mathrm{B}}$ & $7.5^{\mathrm{B}}$ & $7.3^{\mathrm{B}}$ \\
\hline 2 & $8.1^{\mathrm{AB}}$ & $8.2^{\mathrm{AB}}$ & $8.3^{\mathrm{AB}}$ & $8.2^{\mathrm{AB}}$ & $8.3^{\mathrm{A}}$ \\
\hline
\end{tabular}

*: Means in a columns showing the same letter are not significantly different $(\mathrm{p}>0.05)$ 


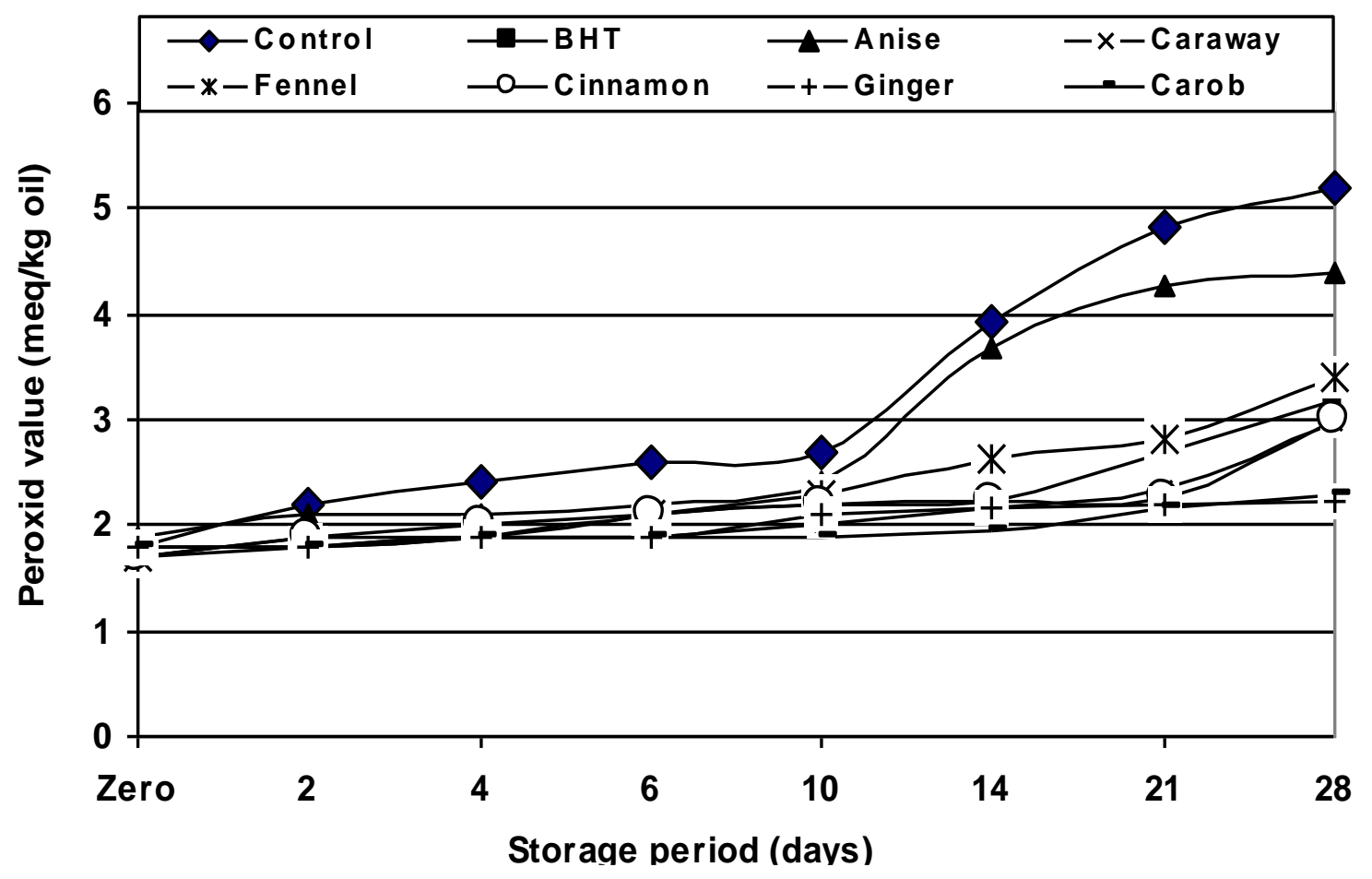

Figure 7. Peroxid values of filling cream containing tested spices during storage at room temperature

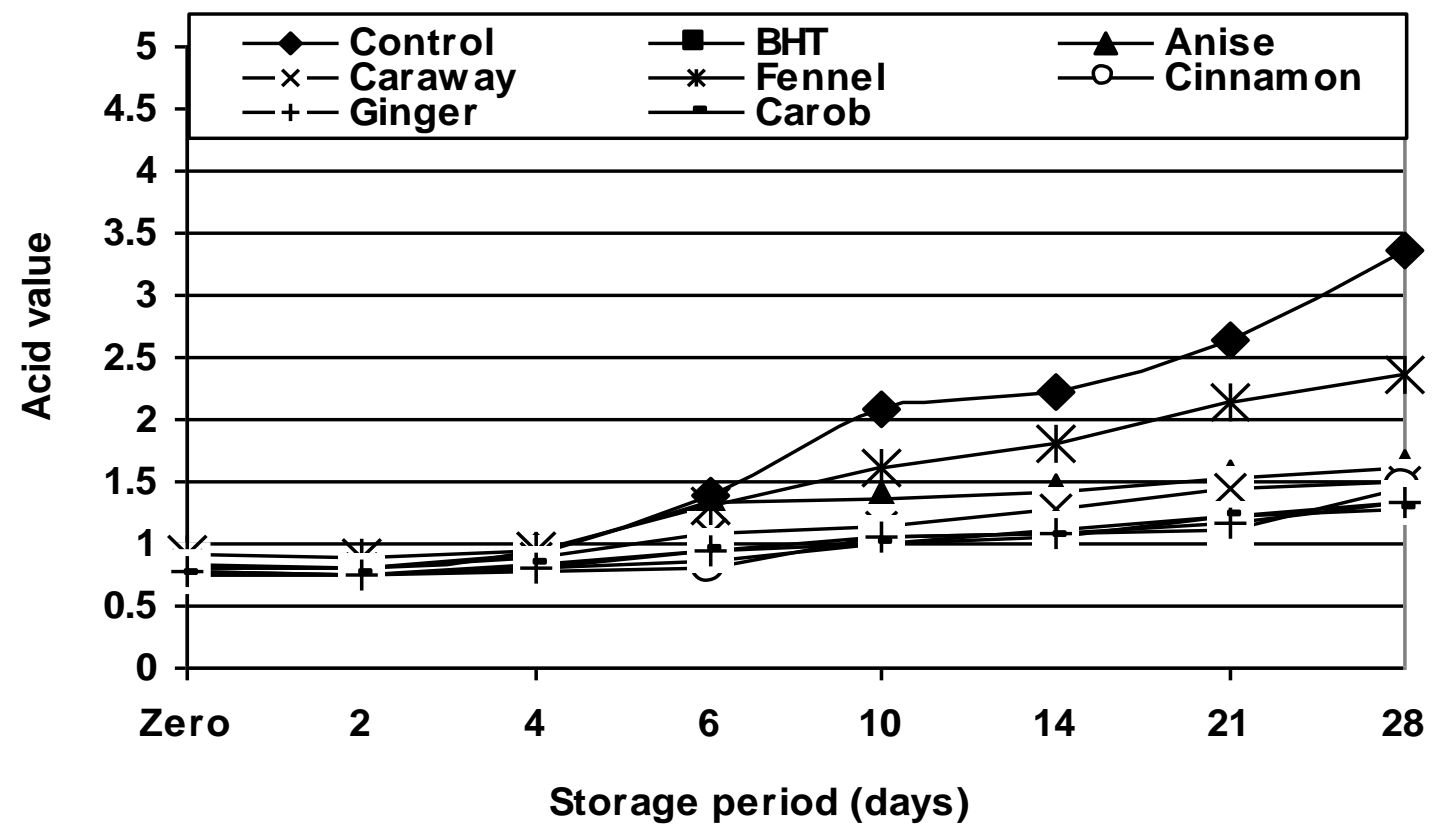

Figure 8. Acid value of filling cream containing some spices during storage at room temperature 
containing $1 \%$ of each, increasing the added level more than $1 \%$, it impaired the filling cream acceptability. Therefore, the concentration of $2 \%$ of anise, fennel, ginger and carob was chosen to test their effectiveness against oxidation of lipid in filling cream, while the chosen concentration of caraway and cinnamon was $1 \%$.

\subsubsection{Moisture content of filling cream dur- ing storage}

Moisture content of filling cream containing some spices showed an stable or slightly increase during storage for 28 days. It ranged between (0.60 to $0.82 \%$ ) from zero to 28 day respectively.

\subsubsection{Measurements of lipid oxidation}

\subsubsection{Peroxide value (PV)}

Changes occurring in PV values of the filling cream containing the best chosen concentrations of tested spices during storage at room temperature are given in Fig. (7). All samples showed an increase in PV with increasing storage period. PV of lipid extracted from control sample reached 5.2 $\mathrm{meq} / \mathrm{kg}$ oil after 28 days. The lower PV was observed in the filling cream containing ginger, car$\mathrm{ob}$ and caraway being 2.22, 2.30 and $2.96 \mathrm{meq} / \mathrm{kg}$ oil respectively compared with synthetic antioxidant BHT (3.18 meq $/ \mathrm{kg}$ oil), after 28 days of storage. These results are in accordance with those of Reddy, et al (2005) who mentioned that the peroxide value of biscuits containing plant extracts increase with increased time of storage compared with control sample.

\subsubsection{Acid value (AV)}

The acid value of filling cream containing the best chosen concentrations of tested spices during storage at room temperature is summarized in Fig. (8). The AV of all samples increased with increasing the storage period. The highest AV was observed in control sample and filling cream containing anise and fennel being 3.36, 1.61 and 2.35, respectively after 28 days. Filling cream containing carob and ginger recorded the same effect of BHT. These results are similar to that of Karpinska et al (2001).

\subsubsection{Sensory evaluation of filling cream during storage}

The sensory properties of filling cream containing the chosent concentrations of the tested spices during storage at room temperature are given in Table (5). Filling cream containing cinnamon, caraway and carob showed significantly superior overall acceptability than control and other samples after 28 days. The minimum reduction in overall acceptability was observed after 6 days in filling cream containing BHT and control sample. It can be noticed that filling cream containing cinnamon, caraway, ginger and carob were comparable to those sample containing BHT and control sample being able to maintain the quality of filling cream during storage for 28 day.

\section{REFERENCES}

A.O.A.C. (2000) Official Methods of Analysis $\left(\mathbf{1 7}^{\text {th }}\right.$ Ed.): Association of Official Analytical Chemists. Gaithers burg, MD, USA.

Archer, A.W. (1988). Determination of cinnamlddehyde, coumarin and cinnamyl alcohol, in cinnamon and cassia by high-performance liquid chromatography. Journal of Chromatography. 447: 272-276.

Bennion, E.B. and G.S.T. Bamford (1983). Cake making process. In: The Technology of Cake Making. $5^{\text {th }}$ (Ed.), pp. 225-230. Leonard Hill Book, London.

Decker, E.A.; W.K.M. Chan; S.A. Livisay; D.A. Butterfield and C. Faustmam (1995). Interaction between carnosine and the different redox states of myoglobin. Journal of Food Science, 60: 12011204.

Farrell, K.T. (1985). Spices, Condiments and Seasoning. pp. 30-127. The AVI Publishing Compaing, Inc. Westport, Connecticut. U.S.A.

Greally, P.; F.J. Hampton and U.M. Macfadyen (1992).Gaviscon and carobel compared with cisapride in gastroeophageal reflux. Arch. Dis. Child., 67: 618-621.

Gulcin, I.; M. Oktay; E. Kirecci and O.I. Kufrevioglu (2003). Screening of antioxidant and antimicrobial actitvities of anise (Pimpinella anisum L.) seed extracts, Food Chemistry 83: 371382.

Jeffery, M.S. (1993). Key functional properties of sucrose in chocolate and sugar Confectionery, Food Technology, January: 141-144.

Karpinska, M.; J. Borowsk and D. Oziewicz (2001). The use of natural antioxidants in readyto-serve food. Food Chemistry 72: 5-9.

Kosar, M.; B. Bozan; F. Temelli and K.H.C. Baser (2007). Antioxidant activity and phenolic composition of sumac (Rhus coriaria L.), Food Chemistry, 103: 952-959. 
Lean, L.P. and S. Mohamed (1999). Antioxidative and antimycotic effects of turmeric, Lemongrass, betel leaves, clove, black pepper leaves and garcinia, atriviridis butter on Cakes. Journal of the Science of Food and Agriculture, 79: 18171822.

Linderschmidt, R.; A. Trylka; M. Goad and H. Witschi (1986). The effects of dietry butylated hydroxyl toluene on liver and colon tumor development in mice. Toxicology, 38: 151-160.

Lingnert, H.; K. Vallentin and E.C. Eriksson (1979). Measurement antioxidative in model System. Journal of Food Processing and Preservation, 3: 87-103.

Liu, F. and T.B. Ng (2000). Antioxidative and free radical scavenging activities of selected medicinal herbs. Life Sciences, 66: 725-735.

Morton, J. (1987). Carob. Fruits of Warm Climates : 65-69.

Moure, A.; J.M. Cruz; D. Franco; M. Dominguez; J. Sineiro; H. Dominguez and M.J. Nunez (2001). Natural antioxidants residual sources. Food Chemistry 72:145-171.

Puertas-Meji, M.; S. Hillebrand; E. Stashenko and P. Winterhalter (2002). In vitro radical scavenging activity of essential oils from Columbian plants and fractions from oregano (Origanum vulgare L.) essential oil. Flavour and Fragrance Journal 17: 380-384.

Reddy, V.; A. Urooj and A. Kumar (2005). Evaluation of antioxidant activity of some plant extracts and their application in biscuits. Food Chemistry, 90: 317-321.

SAS. (1996). Stastical Analysis System. SAS User's Guide Release 6.04, Edition Statistics, SAS institute. Inc. Editors, CARY, NC. USA.

Shahidi, F. (2000). Antioxidants in food and food antioxidants, Nahrung, 44: 158-163.

Slinkard, K. and V.L. Singleton (1977). Total phenol analysis : Automation and comparison with manual methods. American Journal of Enology and Viticulture, 28: 49-55.

Strenhagen, L.Q. and R.C. Hoseney (1994). Firming effect in Danish pastry. Cereal Chem., 71(6): 560-563.

Su, L.; J.J. Yin; D. Charles; K . Zhou; J. Moore and L. Yu (2007). Total phenolic contents Chelating capacities and radical-scavenging properties of black peppercorn, nutmeg, rosehip, cinnamon and oregano leaf. Food Chemistry 100: 990-997.

Suhaj, M. (2006). Spice antioxidants isolation and their antiradical activity : a review, Journal of Food Composition and Analysis, 19: 531-537.

Taghizadeh, A. (2007). The effect of ginger on diabetic nephropathy, plasma antioxidant capacity and lipid peroxidation in rats, Food Chemistry, 101(1): 148-153.

Tepe, B.; D. Daferera; A . Sokmen ; M . Sokmen and M. Pplissiou (2005). Antimicrobial and antioxidative activities of the essential oils and various extracts of Saliva tomentosa miller (Lamiaceae). Food Chemistry, 90: 333 -340.

Wojdylo, A.; J. Oszmianski and R. Czemerys (2007). Antioxidant activity and phenolic compound in 32 herbs, Food Chemistry 105: 940949.

Yamaguchi, T.; H. Takamura;T. Matoba and J. Terao (1998). HPLC method for the evaluation of the free radical scavenging activity of foods by using 2,2-diphenyl-picrylhydrazyl, Bioscience Biotecnology and Biochemistry, 62: 12011204 .

Yen, G.C. and Y. Chuang (2002). Antioxidant properties of water extracts from (Cassia tora L .) in relation to the degree of roasting, Journal, Agriculture. Food Chemistry, 48: 2760-2765.

Zheng, W. and S.Y. Wang (2001). Antioxidant activity and phenolic compounds in selected herbs. Journal of Agricultural and Food Chemistry, 49: 5165-5170. 